\title{
Growth and Leaf Nutrient Status in Banana cv. Grand Naine (AAA) as Influenced by Different Organic Amendments
}

\author{
S. Firoz Hussain ${ }^{1 *}$, Lakshminarayana Reddy ${ }^{1}$ and Venkata Ramudu ${ }^{2}$ \\ ${ }^{1}$ Dr YSRHU, Venkataramannagudem, Andhra Pradesh, India \\ ${ }^{2}$ SKCHS, Anantapuramu, Andhra Pradesh, India \\ *Corresponding author
}

\section{A B S T R A C T}

A field study was undertaken at College of Horticulture, Anantharajupet during the years 2012 - 2013 to investigate the possible effects of inorganic nutrients in combination of organic manures (Farmyard manure and Vermicompost) concomitant with biofertilizers viz., Azospirillum, Phosphate Solubilizing Bacteria (PSB) and Frateuria aurantia (FA) applied at different levels of concentrations. The results showed that highest plant height $(129.67 \mathrm{~cm})$ at 3 MAP (months after planting) and 5 MAP $(184.29 \mathrm{~cm})$, pseudostem girth at 3 MAP $(35.61 \mathrm{~cm})$ and 5 MAP $(49.74 \mathrm{~cm})$, higher nitrogen concentration in index leaf at $3 \mathrm{MAP}(2.93 \%)$ and $5 \mathrm{MAP}(3.28 \%)$, phosphorus content at $3 \mathrm{MAP}(0.26 \%)$ and 5 MAP $(0.24 \%)$ and potassium content at 5 MAP $(3.54 \%)$ were apparent with application

\section{Keywords}

Banana, Grand Naine, Growth and leaf nutrient status.

Article Info

Accepted:

17 October 2017

Available Online:

10 December 2017 of $80 \%$ RDF (inorganic nutrients) viz., Nitrogen (43.4 g), Phosphorus (40 g) and Potassium $(33.3 \mathrm{~g})$ plant $^{-1}$ in combination of organic manures i.e. $20 \% \mathrm{RDN}$ (Vermicompost@4.285 kg plant ${ }^{-1}$ ) along with biofertilizers (Azospirillum, PSB @ $50 \mathrm{~g}$ plant $^{-1}$ and FA @ $25 \mathrm{~g} \mathrm{plant}^{-1}$ ) while application of $80 \%$ RDF (inorganic nutrients) viz., Nitrogen (43.4 g), Phosphorus (40 g) and Potassium (33.3 g) plant ${ }^{-1}$ in combination of organic manures i.e. $20 \%$ RDN (Farmyard manure @ $5.309 \mathrm{~kg} \mathrm{plant}^{-1}$ ) along with biofertilizers (Azospirillum, PSB @ $50 \mathrm{~g} \mathrm{plant}^{-1}$ and FA @ $25 \mathrm{~g} \mathrm{plant}^{-1}$ ) has registered maximum retention of functional leaves at 3 MAP (10.58) and shooting (15.75) concomitant with highest leaf area $\left(3.87 \mathrm{~m}^{2}\right)$ at $3 \mathrm{MAP}$, higher nitrogen $(2.88 \%)$ and phosphorus contents $(0.24 \%)$ in index leaves at shooting stages along with highest potassium content $(3.25 \%)$ at 3 MAP and shooting $(3.42 \%)$. From this study, it can be inferred that both treatments i.e. $80 \%$ RDF (inorganic nutrients) viz., Nitrogen (43.4 g), Phosphorus (40 g) and Potassium (33.3 g) plant $^{-1}$ in combination of organic manures i.e. $20 \%$ RDN (Vermicompost @ $4.285 \mathrm{~kg} \mathrm{plant}^{-1}$ ) along with biofertilizers (Azospirillum, PSB @ $50 \mathrm{~g} \mathrm{plant}^{-1}$ and FA @ $25 \mathrm{~g} \mathrm{plant}^{-1}$ ) and $80 \% \mathrm{RDF}$ (inorganic nutrients) viz., Nitrogen (43.4 g), Phosphorus (40 g) and Potassium (33.3 g) plant ${ }^{-1}$ in combination of organic manures i.e. $20 \%$ RDN (Farmyard manure @ $5.309 \mathrm{~kg} \mathrm{plant}^{-1}$ ) along with biofertilizers (Azospirillum, PSB @ $50 \mathrm{~g} \mathrm{plant}^{-1}$ and FA @ $25 \mathrm{~g} \mathrm{plant}^{-1}$ ) were involved in improving growth and leaf nutrient concentrations in banana at different growth stages of plant life.

\section{Introduction}

Banana (Musa spp) has emerged as the major cash - subsistence crop across the world
(Robinson, 1996) and it is grown in almost all parts of the world specially in the tropical 
regions. In the world of fruits, banana is a complete food fruit packed with all the necessary energy and health giving elements (Anon, 1969). On account of these properties combined with delicious taste and flavor, it is in great demand in fresh as well as processed form all over the world and has gained commercial popularity in the international fruit trade (Thomas et al., 1968).

India leads the globe in total acreage and production of banana. In India, it is being grown in area of $0.85 \mathrm{~m}$ ha with an annual production of 29.16 MT and productivity $34.30 \mathrm{t} \mathrm{ha}^{-1}$ (Anon, 2016). Amongst all the fruit crops in India, the area and production share of banana is $13 \%$ and $31.40 \%$. Banana is a heavy feeder of nutrients and requires large quantities for its growth, development and yield (Hazarika and Ansari, 2010).

The increase in productivity also enhanced the use of chemical fertilizers causing serious damage to environment and health. Heavy organic manuring is required to equalize chemical fertilization (Lahav, 1973) which is practically not possible. Therefore, in this study, it has been planned to use inorganic nutrients $(\mathrm{N}, \mathrm{P}$ and $\mathrm{K}$ ) integrated with organic manures (Vermicompost and farmyard manure) concomitant with biofertilizers for its sustainable growth and production. Integrated nutrient management is the use of chemical fertilizers, organic manures and biofertilizers all at a time in a definite sequence during the growth and developmental stages of a plant for economic and efficient use of nutrients without having any adverse effects on soil health and environment.

Biofertilizers are inputs containing microorganisms capable of mobilizing nutritive elements from non-usable form to usable form through biological processes. They are less expensive, eco-friendly and sustainable.

\section{Materials and Methods}

The present study was conducted during the years 2012 - 13 at College of Horticulture, Anantharajupet which is located at an altitude of 215 meters above mean sea level at $13.98^{0}$ North latitude and $79.40^{\circ}$ East longitude, respectively. The maximum and minimum temperatures during the experiment were $39.03^{\circ} \mathrm{C}$ and $31.0^{\circ} \mathrm{C}$ and relative humidity during the period of crop growth ranged between 77.0 to $87.0 \%$ respectively. The experiment consisted of eleven treatments which were replicated thrice and the statistical design used was Randomized Block Design (RBD). The treatments included were $\mathrm{T}_{1}-$ $100 \%$ Recommended dose of fertilizers (RDF) 300:50:300 g NPK plant ${ }^{-1}$ crop cycle $^{-1}$, $\mathrm{T}_{2}-80 \%$ RDF 240:40:240 g NPK plant $^{-1}$ crop cycle $^{-1}$ through inorganic fertilizers +20 $\%$ RDN through vermicompost (VC), $\mathrm{T}_{3}-80$ $\%$ RDF through inorganic fertilizers $+20 \%$ RDN through $\mathrm{VC}+$ Azospirillum, $\mathrm{T}_{4}-80 \%$ $\mathrm{RDF}$ through inorganic fertilizers $+20 \%$ RDN through $\mathrm{VC}+$ Phosphate solubilizing bacteria (PSB), $\mathrm{T}_{5}-80 \% \mathrm{RDF}$ through inorganic fertilizers $+20 \% \mathrm{RDN}$ through VC + Frateuria aurantia (FA), $\mathrm{T}_{6}-80 \% \mathrm{RDF}$ through inorganic fertilizers $+20 \%$ RDN through $\mathrm{VC}+$ Azospirillum $+\mathrm{PSB}+\mathrm{FA}, \mathrm{T}_{7}-$ $80 \%$ RDF through inorganic fertilizers +20 $\%$ RDN (Farmyard manure (FYM), $\mathrm{T}_{8}-80 \%$ RDF through inorganic fertilizers + $20 \%$ RDN (FYM) + Azospirillum, $\mathrm{T}_{9}-80 \% \mathrm{RDF}$ through inorganic fertilizers $+20 \% \mathrm{RDN}$ $(\mathrm{FYM})+\mathrm{PSB}, \mathrm{T}_{10}-80 \% \mathrm{RDF}$ through inorganic fertilizers $+20 \%$ RDN (FYM) + FA and $\mathrm{T}_{11}-80 \%$ RDF through inorganic fertilizers $+20 \%$ RDN (FYM) + Azospirillum $+\mathrm{PSB}+\mathrm{FA}$.

Calculated quantities of organic manures (Vermicompost @ $4.285 \mathrm{~kg}$ plant $^{-1}$ and Farmyard manure @ 5.309 kg plant ${ }^{-1}$ ) along with biofertilizers viz., Azospirillum (50 g), Phosphate solubilizing bacteria (50 g) and 
Frateuria aurantia (25 g) were applied directly to the pits prior to planting. Observations on growth parameters like plant height, pseudostem girth, number of functional leaves and leaf area were recorded at various stages of crop growth. However, leaf NPK concentrations were analyzed by Kjeldahl, vanadomolybdate and flame photometer methods.

The data was analyzed as per the method of variance outlined by Panse and Sukhatme (1985). Statistical significance was tested by $\mathrm{F}$ value at $5 \%$ level of significance. Critical difference at 0.05 levels was worked out for the effects which were significant.

\section{Results and Discussion}

\section{Growth parameters}

It is conspicuous from Table 1 that significant differences were apparent with respect to plant growth and its attributes viz., plant height, pseudostem girth, functional leaves and leaf area at various stages of crop growth.

Application of $80 \%$ RDF through inorganic fertilizers $+20 \%$ RDN through VC along with Azospirillum, PSB and FA has recorded significantly highest plant height $(129.67 \mathrm{~cm})$ at $3 \mathrm{MAP}$ and $5 \mathrm{MAP}(184.29 \mathrm{~cm})$ and pseudostem girth at 3 MAP $(35.61 \mathrm{~cm})$ and 5 MAP $(49.74 \mathrm{~cm})$. Maximum number of functional leaves at 3 MAP (10.58) and shooting stages (15.75) and highest leaf area $\left(3.87 \mathrm{~m}^{2}\right)$ at 3 MAP were registered with application of $80 \%$ RDF through inorganic fertilizers $+20 \%$ RDN through FYM along with Azospirillum, PSB and FA.

Improvement in plant height and pseudostem girth with different INM treatments as that of inorganic treatments might be ascribed to the involvement of biofertilizers such as Azospirillum, PSB and FA and organic amendments viz., vermicompost and farmyard manure. Ramasamy (1976) reported the role of phosphorus in improving the plant height in banana. Retention of functional leaves in plants that received different INM treatments at $3 \mathrm{MAP}$ and shooting can be explained by the involvement of inorganic nutrients which supply nutrients immediately in assimilable form and organic manures viz., vermicompost and farmyard manure might have released plant growth substances which might have delayed the senescence of leaves and ultimately resulted in retention of more functional leaves than the $100 \%$ RDF application. These results are in agreement with the findings of Dutta et al., (2010) in litchi cv. Bombai. Maintenance of highest leaf area at $3 \mathrm{MAP}$ and $5 \mathrm{MAP}$ in the plants that received different INM treatments could be attributed to the active role of biofertilizers which might have supplied the nutrients as per plant requirement particularly potassium solubilizing bacteria Frateuria aurantia which might have solubilized unavailable potassium in to available form through the secretion of organic acids and enzymes. Potassium has a prominent role in the improvement of leaf area and dry matter production within the plant which ultimately resulted in leaf expansion. Similar observations were in concurrence with findings of Kanamadi et al., (2004).

\section{Leaf NPK status}

\section{Nitrogen}

Data presented in Table 2 denotes that significant differences were reported pertaining leaf NPK status in the index leaf at all stages of plant growth. Application of 80 $\%$ RDF through inorganic fertilizers $+20 \%$ RDN through VC along with Azospirillum, PSB and FA has recorded highest nitrogen concentration at 3 MAP (2.93\%) and (3.28 $\%)$ at 5 MAP. 
Table.1 Influence of different INM treatments on vegetative growth parameters of banana cv. Grand Naine (AAA)

\begin{tabular}{|c|c|c|c|c|c|c|c|c|c|c|c|c|}
\hline \multirow[t]{2}{*}{ Treatments } & \multicolumn{3}{|c|}{ Plant height (cm) } & \multicolumn{3}{|c|}{ Pseudostem girth (cm) } & \multicolumn{3}{|c|}{ Leaf area $\left(\mathrm{m}^{2}\right)$} & \multicolumn{3}{|c|}{ Functional leaves } \\
\hline & $3 \mathrm{M}$ & $5 \mathrm{M}$ & $\mathbf{S}$ & $3 \mathrm{M}$ & $5 M$ & $\mathbf{S}$ & $3 \mathbf{M}$ & $5 \mathrm{M}$ & $\mathbf{S}$ & $3 \mathrm{M}$ & $5 M$ & $\mathbf{S}$ \\
\hline $\mathbf{T}_{1}: 100 \% \mathrm{RDF}$ & 112.72 & 167.43 & 201.96 & 31.42 & 44.39 & 50.66 & 3.00 & 6.18 & 10.72 & 8.83 & 13.50 & 14.16 \\
\hline $\begin{array}{l}\mathbf{T}_{2}: 80 \% \mathrm{RDF}+20 \% \\
\text { RDN through VC }\end{array}$ & 118.15 & 163.37 & 196.46 & 33.31 & 44.41 & 49.08 & 2.96 & 6.86 & 9.59 & 9.25 & 13.58 & 14.00 \\
\hline $\mathbf{T}_{3}: \mathrm{T}_{2}+$ Azospirillum & 117.68 & 166.78 & 198.62 & 32.62 & 44.57 & 50.83 & 2.95 & 6.34 & 8.82 & 9.08 & 13.33 & 14.00 \\
\hline $\mathbf{T}_{\mathbf{4}}: \mathrm{T}_{2}+\mathrm{PSB}$ & 124.01 & 173.29 & 204.50 & 33.66 & 45.48 & 53.12 & 2.76 & 7.24 & 10.19 & 8.58 & 13.66 & 13.88 \\
\hline$T_{5}: T_{2}+F A$ & 121.30 & 172.77 & 200.67 & 32.81 & 44.91 & 51.66 & 3.24 & 7.47 & 10.64 & 10.08 & 14.00 & 14.66 \\
\hline $\begin{array}{l}\mathbf{T}_{6}: \mathrm{T}_{2}+\text { Azospirillum } \\
+\mathrm{PSB}+\mathrm{FA}\end{array}$ & 129.67 & 184.29 & 201.96 & 35.61 & 49.74 & 50.00 & 3.81 & 8.76 & 12.30 & 10.50 & 14.58 & 15.50 \\
\hline $\begin{array}{l}\mathbf{T}_{7}: 80 \% \text { RDF }+20 \% \\
\text { RDN through + FYM }\end{array}$ & 118.99 & 172.13 & 203.04 & 32.29 & 48.27 & 50.33 & 2.96 & 6.90 & 10.38 & 9.16 & 13.83 & 13.75 \\
\hline $\mathbf{T}_{8}: \mathrm{T}_{7}+$ Azospirillum & 114.17 & 176.00 & 201.54 & 31.51 & 45.78 & 50.20 & 3.00 & 6.59 & 9.84 & 9.66 & 13.33 & 13.83 \\
\hline $\mathbf{T}_{\mathbf{9}}: \mathrm{T}_{7}+\mathrm{PSB}$ & 119.53 & 158.21 & 190.29 & 33.17 & 45.21 & 48.04 & 2.68 & 6.72 & 9.60 & 8.75 & 13.33 & 14.25 \\
\hline $\mathbf{T}_{10}: \mathrm{T}_{7}+\mathrm{FA}$ & 121.37 & 167.37 & 206.42 & 32.62 & 44.85 & 51.62 & 3.13 & 7.55 & 10.88 & 9.66 & 13.50 & 14.00 \\
\hline $\begin{array}{l}\mathbf{T}_{11}: \mathrm{T}_{7}+ \\
\text { Azospirillum }+ \text { PSB }+ \\
\text { FA }\end{array}$ & 125.26 & 178.75 & 197.04 & 35.24 & 48.93 & 50.95 & 3.87 & 7.55 & 11.52 & 10.58 & 14.08 & 15.75 \\
\hline Mean & 120.25 & 170.94 & 200.22 & 33.11 & 46.04 & 50.59 & 3.12 & 7.105 & 10.40 & 9.46 & 13.70 & 14.34 \\
\hline S.Em. $( \pm)$ & 2.97 & 4.18 & 5.89 & 0.72 & 1.24 & 1.60 & 0.13 & 0.50 & 0.85 & 0.24 & 0.27 & 0.24 \\
\hline C.D. $(\mathrm{P}=0.05)$ & 8.83 & 12.41 & N.S. & 2.12 & 3.67 & N.S. & 0.38 & N.S. & N.S. & 0.72 & N.S. & 0.71 \\
\hline
\end{tabular}

$\mathrm{M}$ - Months after planting, S - Shooting, RDF - Recommended dose of fertilizers, RDN - Recommended dose of nitrogen, PSB - Phosphate solubilizing bacteria, FA - Frateuria aurantia

Table.2 Influence of different inorganic and organic sources of nutrients along with biofertilizers on NPK content in leaf tissue of Banana cv. Grand Naine (AAA)

\begin{tabular}{|c|c|c|c|c|c|c|c|c|c|}
\hline \multirow[t]{2}{*}{ Treatments } & \multicolumn{3}{|c|}{ Nitrogen $(\%)$} & \multicolumn{3}{|c|}{ Phosphorus } & \multicolumn{3}{|c|}{ Potassium } \\
\hline & $3 \mathbf{M}$ & $5 \mathrm{M}$ & $\mathbf{S}$ & $3 \mathbf{M}$ & $5 \mathrm{M}$ & $\mathbf{S}$ & $3 \mathbf{M}$ & $5 \mathrm{M}$ & $\mathbf{S}$ \\
\hline $\mathbf{T}_{\mathbf{1}}: 100 \% \mathrm{RDF}$ & 2.20 & 2.85 & 2.60 & 0.18 & 0.20 & 0.20 & 2.65 & 3.18 & 2.70 \\
\hline $\begin{array}{l}\mathbf{T}_{2}: 80 \% \mathrm{RDF}+20 \% \\
\mathrm{RDN} \text { through VC }\end{array}$ & 2.06 & 2.56 & 2.40 & 0.23 & 0.21 & 0.17 & 2.67 & 2.81 & 2.44 \\
\hline $\mathbf{T}_{\mathbf{3}}: \mathrm{T}_{2}+$ Azospirillum & 2.79 & 3.12 & 2.76 & 0.23 & 0.19 & 0.18 & 2.73 & 3.16 & 2.64 \\
\hline $\mathbf{T}_{4}: \mathrm{T}_{2}+\mathrm{PSB}$ & 2.13 & 2.95 & 2.62 & 0.26 & 0.24 & 0.20 & 2.51 & 3.11 & 2.54 \\
\hline $\mathbf{T}_{\mathbf{5}}: \mathrm{T}_{2}+\mathrm{FA}$ & 2.17 & 2.95 & 2.36 & 0.20 & 0.21 & 0.18 & 3.16 & 3.33 & 2.95 \\
\hline $\begin{array}{l}\mathbf{T}_{\mathbf{6}}: \mathrm{T}_{2}+\text { Azospirillum }+ \\
\mathrm{PSB}+\mathrm{FA}\end{array}$ & 2.93 & 3.28 & 2.76 & 0.16 & 0.22 & 0.17 & 3.24 & 3.54 & 3.10 \\
\hline $\begin{array}{l}\mathbf{T}_{7}: 80 \% \mathrm{RDF}+20 \% \\
\text { RDN through }+ \text { FYM }\end{array}$ & 2.04 & 2.72 & 2.04 & 0.19 & 0.19 & 0.19 & 2.16 & 2.76 & 2.28 \\
\hline $\mathbf{T}_{8}: \mathrm{T}_{7}+$ Azospirillum & 2.55 & 3.07 & 2.72 & 0.19 & 0.19 & 0.19 & 2.16 & 2.76 & 2.28 \\
\hline $\mathbf{T}_{9}: \mathrm{T}_{7}+\mathrm{PSB}$ & 2.08 & 2.77 & 2.31 & 0.21 & 0.21 & 0.24 & 2.49 & 3.02 & 2.90 \\
\hline $\mathbf{T}_{10}: \mathrm{T}_{7}+\mathrm{FA}$ & 2.35 & 3.03 & 2.39 & 0.23 & 0.19 & 0.19 & 2.86 & 3.22 & 3.06 \\
\hline $\begin{array}{l}\mathbf{T}_{11}: \mathrm{T}_{7}+\text { Azospirillum }+ \\
\mathrm{PSB}+\mathrm{FA}\end{array}$ & 2.78 & 3.19 & 2.88 & 0.26 & 0.21 & 0.19 & 3.25 & 3.46 & 3.42 \\
\hline Mean & 2.37 & 2.95 & 2.53 & 0.21 & 0.20 & 0.19 & 2.17 & 3.12 & 2.75 \\
\hline S.Em. $( \pm)$ & 0.09 & 0.10 & 0.10 & 0.02 & 0.01 & 0.01 & 0.17 & 0.10 & 0.20 \\
\hline C.D. $(P=0.05)$ & 0.25 & 0.30 & 0.30 & 0.05 & 0.02 & 0.02 & 0.50 & 0.30 & 0.58 \\
\hline
\end{tabular}

M - Months after planting, S - Shooting, RDF - Recommended dose of fertilizers, RDN - Recommended dose of nitrogen, PSB - Phosphate solubilizing bacteria, FA - Frateuria aurantia 
At shooting stage, application of $80 \%$ RDF through inorganic fertilizers $+20 \%$ RDN through FYM along with Azospirillum, PSB and FA has registered highest nitrogen concentration (2.88). It was observed that gradual increase in nitrogen levels in the leaves up to 5 MAP and declined at shooting stage in all the treatments. Plants that received Azospirillum as one of the component have maintained optimum levels of nitrogen (2.50 to $3.00 \%$ as suggested by Bhargava, 1999). This beneficial influence can be attributed to the Azospirillum inoculation which might have fixed atmospheric nitrogen in the soil, in addition to secretion of plant growth promoting substances that usually promotes the growth (Sumner, 1990).

\section{Phosphorus}

It was observed that application of $80 \% \mathrm{RDF}$ through inorganic fertilizers $+20 \%$ RDN through VC along with Azospirillum, PSB and FA has recorded higher phosphorus concentration in index leaf at $3 \mathrm{MAP}(0.26 \%)$ and $(0.24 \%)$ at 5 MAP. Higher phosphorus content in index leaf $(0.24 \%)$ at shooting stage was apparent with application of $80 \%$ RDF through inorganic fertilizers $+20 \%$ RDN through FYM along with PSB. The optimum maintenance of phosphorus concentration at all stages of plant growth might be attributed to PSB inoculation which might have converted unavailable phosphorus into available form through section of organic acids (Table 2).

\section{Potassium}

Higher potassium content in index leaf $(3.25$ $\%)$ at 3 MAP and (3.46\%) at shooting stage were evident with application of $80 \% \mathrm{RDF}$ through inorganic fertilizers $+20 \%$ RDN through FYM along with Azospirillum, PSB and FA. At 5 MAP, $80 \%$ RDF through inorganic fertilizers $+20 \% \mathrm{RDN}$ through $\mathrm{VC}$ along with Azospirillum, PSB and FA has registered higher potassium content $(3.54 \%)$ in index leaf. This effect could be ascribed to the beneficial effect of Frateuria aurantia which could have solubilized unavailable potassium in to available form through its secretion of organic acids and enzymes (Table 2).

\section{References}

Anonymous, 1969. Medicinal secrets of Yarn Food. Pub. Sec., Indo America Hospital. N.R. Mahulla. Mysore, $1^{\text {st }}$ Ed. Pp 183191.

Anonymous, 2016. $2^{\text {nd }}$ Advance Estimate. National Horticulture Board. $\mathrm{Pp}-6$.

Bhargava, B.S. 1999. "Leaf analysis for diagnosing nutrients need in fruit crops', Indian Horticulture. 43(4): 6-8.

Dutta, P, Kundu, S and Biswas, S. 2010. Integrated nutrient management in litchi cv. Bombai in new alluvial zone of West Bengal. Indian Journal of Horticulture. 67: 181-184.

Hazarika, B.N. and Ansari, S. 2010. Effect of Integrated Nutrient Management on growth and yield of banana cv. Jahaji (AAA). Indian Journal of Horticulture. 67: 270-273.

Kanamadi. V.C., Rahul Kumar Bhavidoddo Shirol, A.M., Thimmaiah, N. and Athani, S.I. 2004. Influence of organic and inorganic fertilizers on growth and yield characters of banana cv. Rajapuri. Karnataka Journal of Horticulture. 1(1): 81-85.

Lahav. E. 1973. Effects and interactions of manures and fertilizers in banana plantation. Israel Journal of Agricultural Research. 23 (1):.45-57.

Panse, V.G. and Sukhatme, P.V. 1985. Statistical Methods for Agricultural Workers. ICAR, New Delhi.

Ramasamy, N. 1976. Annamalai. 6 (1): 30-37. Robinson, J.C. 1996. Bananas and Plantains, 
pp. 238. CAB Internationals. Thomas, P, Dulal, W.B., Pushpa, M.C. and Wallingford. UK.

Sumner, M.E. 1990. Crop responses to Azospirillum inoculation. Advances in Agronomy. 12 (1): 141-255.

Amla, B.L. 1968. Harvesting, handling and transportation of bananas for export from India. Indian Food Packer. 22: 1621.

\section{How to cite this article:}

Firoz Hussain S., Lakshminarayana Reddy and Venkata Ramudu. 2017. Growth and Leaf Nutrient Status in Banana cv. Grand Naine (AAA) as Influenced by Different Organic Amendments. Int.J.Curr.Microbiol.App.Sci. 6(12): 2340-2345. doi: https://doi.org/10.20546/ijcmas.2017.612.269 